\title{
STRUKTUR, PERILAKU DAN KINERJA PEMASARAN IKAN CAKALANG DI KABUPATEN HALMAHERA SELATAN
}

\author{
Fauji Yamin ${ }^{1}$, Anna Fariyanti ${ }^{2}$, dan Siti Jahroh ${ }^{3}$ \\ 1,2)Departemen Agribisnis, Fakultas Ekonomi dan Manajemen, Institut Pertanian Bogor \\ Jl. Kamper Wing 4 Level 5 Kampus IPB Dramaga, Indonesia \\ 3)Sekolah Bisnis, Institut Pertanian Bogor \\ Jl. Raya Pajajaran, Kampus IPB Gunung Gede, Kota Bogor, Indonesia \\ e-mail: 1)faujiyamin16@gmail.com
}

(Diterima 29 Mei 2020/Revisi 23 Juni 2020/Disetujui 10 Juli 2020)

\begin{abstract}
Skipjack tuna is the result of the main capture fisheries in the South Halmahera district which experienced significant growth of 4,2 percent during the 2016-2018 period, but increased production experienced constraints in the marketing system and caused income uncertainty for fishermen and traders. The purpose of this study was to determine the marketing system of skipjack tuna in the South Halmahera Regency using a structural, behavioural, and performance (SCP) approach. The sampling method uses snowball sampling which started with 68 fishermen. The results showed that the market structure formed was an oligopsonistic market structure and there was a barrier to market entry of 14 percent. Meanwhile, market behaviour shows that fishermen only act as price takers. Based on the marketing margin analysis, there are 10 (ten) skipjack fish marketing channels. Judging from the value of large skipjack fish, marketing channel 7 has the highest margin value of 70,4 percent and the lowest is channel 8 of 53,9 percent. Meanwhile, the marketing channel of small fish the highest margin value is marketing channel 9 of 73,9 and the lowest is channel 9 of 65,1 percent. While the value of farmer share, channel 1 has the highest value of 70 percent and the lowest is channel 7 of 36 percent. Overall, skipjack tuna marketing channels have not been efficient.
\end{abstract}

Keywords:farmer's share, marketing channels, marketing margins, SCP

\begin{abstract}
ABSTRAK
Ikan cakalang merupakan hasil perikanan tangkap unggulan di kabupaten Halmahera Selatan yang mengalami pertumbuhan signifikan sebesar 4,2 persen selama periode 2016-2018, namun produksi yang meningkat mengalami kendala dalam sistem pemasaran dan menyebabkan ketidakpastian pendapatan bagi nelayan maupun pedagang. Tujuan penelitian untuk mengetahui sistem pemasaran ikan cakalang ikan cakalang di Kabupaten Halmahera Selatan menggunakan pendekatan struktur, perilaku dan kinerja (SCP). Metode pengambilan sampel menggunakan snowball sampling yang dimulai dari 68 nelayan. Hasil penelitian menunjukkan, struktur pasar yang terbentuk ialah struktur pasar oligopsoni dan terdapat hambatan masuk pasar sebesar 14 persen. Sementara, perilaku pasar menunjukan nelayan hanya berperan sebagai price taker. Berdasarkan analisis margin pemasaran, terdapat 10 (sepuluh) saluran pemasaran ikan cakalang.. Di lihat dari nilai margin ikan cakalang besar, saluran pemasaran 7 memiliki nilai margin tertinggi sebesar 70,4 persen dan terendah ialah saluran 8 sebesar 53,9 persen. Sementara, saluran pemasaran ikan kecil nilai margin tertinggi yaitu saluran pemasaran 9 sebesar 73,9 dan terendah ialah saluran 9 sebesar 65,1 persen. Sementara nilai farmer share's, saluran 1 memiliki nilai tertinggi sebesar 70 persen dan terendah ialah saluran 7 sebesar 36 persen. Secara keseluruhan, saluran pemasaran ikan cakalang belum efisien.
\end{abstract}

Kata kunci: farmer's share, margin pemasaran, SCP, saluran pemasaran

\section{PENDAHULUAN}

Karateristik perairan Provinsi Maluku Utara berada di wilayah produksi tuna nasio- nal. Zona ini merupakan wilayah Pengelolaan Perikanan Negara Republik Indonesia (WPPNRI) 715, 716, 717 yang masuk dalam Rencana Pengelolaan Perikanan Tuna, Cakalang dan 
Tongkol (RPP-TCT) lewat Keputusan Menteri Kelautan dan Perikanan Nomor 107/ KEPMEN-KP/2015.

Zona WPP 715 merupakan zona utama penangkapan Tuna, Cakalang dan Tongkol (TCT) dengan total produksi pada tahun 2018 sebesar 286,629,486 ton. Sementara, produksi Maluku Utara pada WPP 715 mencapai 61 persen (174,730 ton) dengan cakalang sebagai komoditi tangkapan utama sebesar 66 persen di banding tuna dan tongkol (DKP Maluku Utara, 2019).

Sentra utama produksi perikanan tangkap cakalang di Provinsi Maluku Utara ialah Kabupaten Halmahera Selatan yang berada tepat di WPP 715. Tren pertumbuhan produksi cakalang di Kabupaten Halmahera Selatan dari tahun 2016-2018 tumbuh sebesar 4,2 persen dengan kontribusi sebesar 74 persen total tangkap komoditas TCT, (PPP Bacan, 2019). Komoditas ini merupakan komoditi andalan bagi nelayan pole and line maupun hand line yang berbasis di PPP Bacan Kecamatan Bacan Selatan.

Produksi yang melimpah menempatkan Kabupaten Halmahera Selatan sebagai sentra tangkap cakalang yang berperan strategis sebagai sumber pendapatan nelayan dan pedagang serta merupakan daerah supplier utama bahan baku industri yang memenuhi permintaan konsumen baik lokal maupun luar daerah yakni Kota Ternate, Manado, Bitung, Surabaya dan Jakarta. Sementara tujuan pasar ekspor utama ialah Jepang, Taiwan, Amerika dan sebagian Eropa, (DKP, 2017).

Tujuan pemasaran baik lokal maupun luar daerah melibatkan berbagai lembaga pemasaran yang dapat menciptakan banyak saluran pemasaran ikan cakalang. Sehingga, menyebabkan harga ikan cakalang lebih berfluktuasi di tingkat konsumen dibandingkan di tingkat nelayan dan pemasaran menjadi tidak efisien. Menurut (Nurmalima et. al 2013; Dilana 2013) pemasaran yang efisien dapat dilihat dari tingkat harga dan stabilisasi harga

Fluktuasi harga merupakan masalah utama yang dihadapi oleh nelayan di sentra produksi. Fluktusi harga yang terjadi di tingkat konsumen lebih tinggi ketimbang fluktuasi harga yang terjadi di tingkat nelayan sehingga dapat mempengaruhi keuntungan nelayan dan pihak-pihak yang terlibat dalam sistem pemasaran ikan cakalang. Di mana, pihak yang lebih dirugikan dari kondisi fluktuasi ialah produsen dari pada pedagang karena dapat mengatur waktu penjualan untuk mendapatkan harga yang menguntungkan (Irawan, 2007).

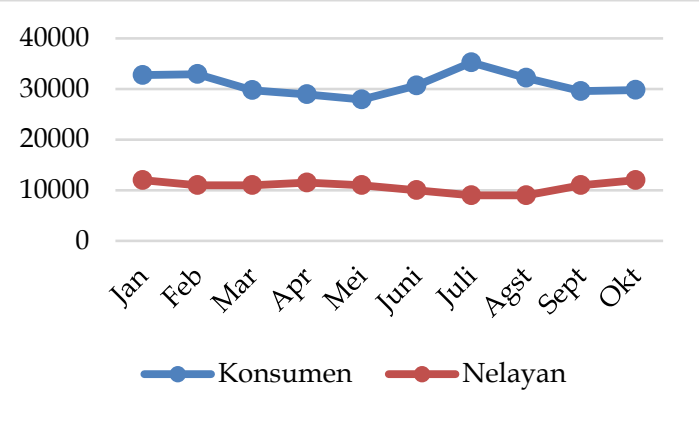

Gambar 1. Fluktuasi Harga Produsen dan Konsumen Kabupaten Halmahera Selatan Tahun 2019.

Sumber : PPP Bacan 2019, BPS 2019

Berdasarkan Gambar 1, fluktuasi harga selama periode Januari-Oktober 2019 menunjukkan, harga tidak berjalan seirama dan terjadi perbedaan yang cukup signifikan. Fluktuasi harga yang terjadi di tingkat konsumen mencapai 29,4 persen sementara di tingkat produsen hanya 7,9 persen. Selain itu, pergerakan harga pada musim paceklik yakni April, Mei dan Juni juga menunjukan perubahan yang tidak berarti di tingkat nelayan. Kondisi ini menurut, Zunaidah et al. (2015) akibat dari transmisi harga antar lembaga pemasaran masih rendah. Rendahnya informasi perbedaan harga antar produsen dan konsumen menyebabkan harga tidak tersampaikan dengan baik sehingga posisi tawar nelayan dalam menentukan harga di pasar sangat lemah.

Fluktuasi harga yang terjadi, selain karena faktor musim tangkap, kondisi permintaan dan penawaran, sentra yang terkonsentrasi di kepulauan dari pada konsumen, posisi tawar nelayan lemah juga di pengaruhi oleh sistem 
pemasaran yang terbentuk di lokasi produksi, (Azahra et.al, 2019).

Sistem pemasaran ikan cakalang di Kabupaten Halmahera Selatan melibatkan berbagai macam saluran pemasaran yang memiliki kepentingan berbeda-beda. Dalam memasarkan hasil tangkap, nelayan lebih banyak menggunakan jasa pedangan perantara.

Peranan penting lembaga pemasaran ini karena hubungan yang terjalin bersifat patron klien dan menyebabkan nelayan tidak memiliki pengaruh dalam penetapan harga serta hanya berperan sebagai price taker. Hubungan patron klien berpengaruh cukup kuat karena selain melakukan fungsi pemasaran, pedagang perantara merupakan sumber permodalan dan kemitraan operasional nelayan. Hal ini sejalan dengan Tain (2011), bahwa sebagian besar nelayan terikat dengan pedagang perantara sebagai agen kreditur sehingga nelayan menerima berapun harga di tetapkan.

Proses penentuan harga ikan dilakukan secara sepihak walaupun transaksi jual beli dilakukan di Pusat Pelelangan Ikan (PPI). Tidak ada proses tawar-menawar yang terjadi di PPI dan mekanisme pembentukan harga mengikuti perkembangan harga beli dari industri perikanan yang beroperasi di PPP Bacan.

Ketergantungan nelayan dengan pedagang perantara membuat nelayan memiliki bargaining position lemah, Apituley 2018). Sehingga menyebabkan pemasaran yang tidak efisien dan dapat membuat nelayan sulit meningkatkan pendapatan Menurut (DKP Malut 2017) ${ }^{4}$, dalam satu musim nelayan ikan di Maluku Utara, pendapatan rata-rata tidak lebih dari Rp 2-5 Juta. Pendapatan ini belum dilakukan pembagian dengan komposisi 40 persen pemilik kapal dan 60 persen ABK. Dalam 60 persen, dibagi untuk kapten 20 persen, bendahara 15 persen, masinis 15 persen serta pemancing 10 persen ${ }^{5}$.

Peran pedagang besar dan industri perikanan dalam pembentukan harga ikan cakalang mengindikasikan struktur pasar mengarah ke persaingan tidak sempurna. Padahal, sebagai produk yang perisable, ikan cakalang memerlukan penanganan yang cepat dengan sistem pemasaran yang baik. Hal ini sejalan dengan penelitian (Hidayanti 2014; Hikmayani et al. 2007) menemukan bahwa struktur pasar yang dihadapi oleh produsen perikanan ialah pasar persaingan tidak sempurna. Kondisi struktur pasar ini menyebabkan mekanisme pasar tidak bekerja dengan sempurna sehingga sistem pemasaran menjadi tidak efisien (Khols dan Uhl, 2002).

Upaya mengatasi permasalahan sistem pemasaran yaitu dengan pendekatan struktur pasar (market structure), perilaku pasar (market conduct) dan kinerja pasar (market performance) (SCP) (Bosena et al. 2011; Funke et al. 2012). Struktur pasar akan menggambarkan tipe atau jenis pasar yang dihadapi oleh nelayan sebagai produsen dan sebagai pelaku pasar. Perilaku pasar menggambarkan kondisi nelayan dan pedagang dalam melakukan aktivitas bisnis dan interaksi antara struktur pasar dan perilaku pasar akan tercermin pada kinerja pasar yang ditunjukan oleh tingkat efisiensi dan keuntungan lembaga pemasaran.

Beberapa penelitian menggunakan konsep SCP, diantaranya (Baiquni, 2019; Apitule et. al, 2019; Membrate \& Worku, 2019) menemukan bahwa struktur pasar perikanan cenderung tidak bersaing sempurna dan mengarah ke oligopsoni serta terdapat hambatan masuk pasar. Perilaku pasar masih merugikan nelayan sebagai produsen dengan sistem pemasaran belum efisien karena terdapat banyak saluran pemasaran yang menyebabkan terdapat perbedaan margin di setiap saluran pemasaran. Berbeda dengan Thabrani, (2018) bahwa struktur pasar ikan hias mendekati pasar persaingan sempurna. Perilaku pasar dalam penentuan harga dilakukan secara tawar-menawar dan kinerja pemasaran pada 3 saluran pemasaran sudah efisien karena meratanya penyebaran rasio keuntungan.

\footnotetext{
4 Berdasarkan artikel https://Nasional.tempo.co/read/674369/80-\%-nelayan-maluku-utara-hidup-miskin

${ }_{5}$ Berdasarkan informasi pra penelitian dengan nelayan di kapal Inka Mina di pelabuhan PPP Bacan pada tanggal 30 september 2018
} 
Sejalan dengan Ramdani et. al (2016) di mana, struktur pasar ikan Salai Patin ialah pasar persaingan sempurna, namun untuk masuk ke pasar terdapat hambatan masuk yang tinggi MES >10 persen. Sementara efisiensi pemasaran pada saluran pemasaran ditemukan berbeda-beda.

Berdasarkan uraian di atas, dapat dirumuskan beberapa permasalahan yang menarik untuk dikaji, yaitu: 1) Bagaimana struktur, perilaku dan kinerja pemasaran ikan cakalang di Kabupaten Halmahera Selatan? 2). Apakah sistem pemasaran ikan cakalang sudah efisien? Sehingga, tujuan penelitian ini ialah menganalisis struktur pasar ikan cakalang di Kabupaten Halmahera Selatan, menganalisis perilaku lembaga-lembaga pemasaran dan menganalisis kinerja pemasaran ikan cakalang.

\section{METODE}

\section{LOKASI DAN WAKTU PENELITIAN}

Penelitian dilakukan di Kabupaten Halmahera Selatan, Kecamatan Bacan Selatan. Lokasi dipilih secara sengaja (purposive) berdasarkan pertimbangan share produksi terbesar. Selain itu pertimbangan kedua lokasi ini karena masuk dalam rancangan wilayah pengembangan industri perikanan dan sentra utama perikanan tangkap cakalang. Waktu penelitian yaitu bulan September 2019 sampai November 2019.

\section{METODE PENGUMPULAN DATA DAN SAMPEL}

Metode Pengumpulan Data dan Penentuan Sampel Data yang digunakan dalam penelitian ini adalah data primer dan data sekunder. Pengumpulan data primer dilakukan langsung oleh peneliti melalui wawancara kepada nelayan dan lembaga-lembaga terkait menggunakan kuesioner.

Data sekunder diperoleh melalui publikasi dan pencatatan langsung dari dinas dan instansi terkait. Selain itu, observasi juga dilakukan peneliti di sentra produksi Kabupaten Halmahera Selatan.
Responden dalam penelitian ini ialah nelayan kapal pole and line, hand line dan lembaga-lembaga pemasaran dengan jumlah 68 responden nelayan, 18 responden pedagang besar, 9 responden pedagang pengumpul kecamatan, 15 responden pengecer, 6 responden pedagang grosir, 8 responden industri olahan dan 7 responden industri perikanan. Pengambilan sampel nelayan dilakukan secara purposive dan lembaga pemasaran dilakukan dengan menggunakan metode snowball sampling.

\section{METODE ANALISIS DATA}

Pendekatan yang digunakan dalam menganalisis pemasaran ikan cakalang yaitu pendekatan struktur pasar (market sctukture), perilaku pasar (market counduct) dan kinerja pasar (market performance). Analisis yang dilakukan adalah analisis desktiptif dan kuantitatif.

\section{ANALISIS STRUKTUR PASAR}

\section{a. Analisis Pangsa Pasar}

Analisis pangsa pasar ikan cakalang dilakukan dengan menghitung pangsa pasar peedagang besar, nelayan, pedagang grosir dan industri perikanan yang melakukan penawaran di Kabupaten Halmahera Selatan.

$$
\text { Pangsa Pasar }=\frac{\mathrm{S}_{\mathrm{n}}}{\mathrm{Sa}} \times 100 \%
$$

Keterangan :

Pangsa Pasar $\left(\mathrm{PP}_{\mathrm{n}}\right)$ : 0-100 persen

Pangsa Pasar $\left(\mathrm{PP}_{\mathrm{n}}\right)$ : Pangsa pasar pedagang besar (persen)

$\mathrm{S}_{\mathrm{n}}=$ Penjualan ikan cakalang oleh pedagang besar (kg/bulan)

$\mathrm{S}_{\mathrm{a}}=$ Total penjualan cakalang di pelabuhan pendaratan ikan (PPP Bacan kg/bulan)

$\mathrm{n}=$ Banyaknya pedagang ikan cakalang

\section{b. Analisis Konsentrasi Pasar}

Perhitungan konsentrasi pasar menggunakan analisis Consentration Ratio for Biggest Four atau CR4 untuk mengetahui derajat konsentrasi 4 pangsa pasar terbesar (Aninditya 
dan Baladina, 2017). Data yang digunakan dalam penelitian ini ialah data sekunder yang terdiri dari data total penjualan harian pedagang besar bulan September 2019, data total penjualan bulanan nelayan bulan September 2019 dan data total penjualan bulanan industri perikanan bulan September 2019 yang diperoleh dari PPP Bacan. Sementara, data yang digunakan untuk mengukur rasio konsentrasi pedagang grosir ialah data primer minguaan yang diperoleh melalui wawancara. Berikut hitungan matematis perhitungan CR4 :

$$
\mathrm{CR} 4=\frac{\mathrm{S}_{1}+\mathrm{S}_{2}+\mathrm{S}_{3}+\mathrm{S}_{4}}{\mathrm{~S}_{\mathrm{n}}}
$$

Keterangan :

$\mathrm{CR}_{4}$ : Konsentrasi Rasio

$S_{1} \quad$ : Penjualan pedagang besar ikan cakalang 1 ( $\mathrm{kg} /$ bulan)

$\mathrm{S}_{2} \quad$ : Penjualan pedagang besar ikan cakalang 2 (kg/bulan)

$\mathrm{S}_{3} \quad$ : Penjualan pedagang besar ikan cakalang 3 (kg/bulan)

$\mathrm{S}_{4} \quad$ : Penjualan pedagang besar ikan cakalang 4 (kg/bulan )

$S_{n} \quad$ : Total penjualan ikan cakalang pedagang besar ( $\mathrm{kg} /$ bulan)

\section{c. Hambatan Keluar Masuk Pasar}

Hambatan keluar masuk pasar dihitung menggunakan Minimum efficiency Scale (MES) yaitu perhitungan pembelian yang dilakukan oleh lembaga pemasaran terhadap total pembelian lembaga pemasaran. Menurut Jaya (2001), jika nilai MES > 10 persen, maka mengindikasikan terdapat hambatan masuk pasar. Kajian struktur pasar dengan pendekatan MES pernah dilakukan oleh Putri et, al (2013) dengan hasil MES 28,53 persen dan AlBaiquni, (2019) menemukan nilai MES > 10 persen. Berikut perhitungan MES :

Pembelian cakalang pedagang terbesar.

$$
\text { MES }=\frac{\text { Total ikan cakalang di pasar }}{\text { Th }}
$$

Keterangan :

MES = Minimum Efficiency Scale

\section{ANALISIS PERILAKU PASAR}

Perilaku pasar merupakan perilaku partisipan pembeli dan penjual, starategi atau reaksi yang dilakukan partisipan pasar secara individu atau kelompok, dalam hubungan kompetitif atau negoisiasi terhadap partisipan lainnya untuk mencapai tujuan pemasaran dalam struktur tertentu, Asmarantaka (2014). Perilaku pasar akan ditelaah secara mendalam baik secara deskriptif dan kuantitatif menggunakan indikator fungsi pemasaran, sistem penentuan harga dan pembayaran, serta kerjasama antar berbagai lembaga pemasaran.

\section{KINERJA PEMASARAN}

Kinerja pasar di analisis dalam penelitian ini ialah efisiensi operasional. Yaitu marjin pemasaran, farmer's share, serta komponen biaya dan manfaat dari efisiensi pemasaran.

\section{a. Analisis Margin Pemasaran}

Analisis dalam penelitian ini didasarkan pada data primer yang dikumpulkan dari setiap lembaga pemasaran mulai produsen sampai konsumen. Analisis margin pemasaran dilakukan untuk mengetahui perbedaan harga yang diterima produsen $(\mathrm{Pf})$ dengan harga yang dibayarkan konsumen (Pr). Berikut hitungan matematis margin pemasaran sebagai berikut :

$$
\begin{gathered}
\mathrm{MT}=\sum \mathrm{mi}=\mathrm{P}_{\mathrm{r}}-\mathrm{P}_{\mathrm{f}}=\mathrm{C}_{\mathrm{i}}+\pi i \\
\text { Sumber: Asmarantaka (2014) }
\end{gathered}
$$

Dimana :

MT : Total margin ikan cakalang

Pf : Harga ikan cakalang di tingkat nelayan

Pr : Harga ikan di tingkat konsumen

Mi : Margin pemasaran pada lembaga pemasaran ikan ke-i

$\mathrm{Ci}$ : Biaya lembaga pemasaran tingkat ke-i

пі : Keuntungan tingkat ke-i

Perhitungan marjin pemasaran total dapat dilakukan dengan menggunakan persentase. Marjin pemasaran dalam bentuk persentase sering digunakan sebagai indikator efisiensi 
dalam pemasaran karena lebih mudah untuk dibandingkan. Adapun rumus sistematis sebagai berikut:

$$
\mathrm{MT}=\operatorname{Pr}-\operatorname{Pf} \operatorname{Pr} x 100 \%
$$

Sumber: Asmarantaka (2014)

Sementara, keuntungan adalah selisih antara total penerimaan dan total biaya yang digunakan, Soekartawi (1998). Secara matematis keuntungan pemasaran tiap lembaga pemasaran sebagai berikut:

$$
\mathrm{Kp}_{\mathrm{n}}=\mathrm{PS}_{\mathrm{n}}-\mathrm{Pb}_{\mathrm{n}}-\mathrm{B} \mathrm{p}_{\mathrm{n}}
$$

Keterangan:

$K p_{n}$ : Keuntungan lembaga pemasaran ke-n

$\mathrm{Pb}_{\mathrm{n}}$ : Harga beli ikan cakalang lembaga pemasaran ke-n

$P_{s_{n}}$ : Harga jual ikan cakalang lembaga pemasaran ke-n

Bpn : Biaya pemasaran ikan cakalang

\section{b. Farmer's Share}

Farmer's share merupakan rasio harga ditingkat nelayan dan harga ditingkat konsumen akhir. Berikut ini rumus farmer share secara matematis:

$$
\begin{gathered}
\mathrm{F}^{\prime} \mathrm{s}=\mathrm{P} f / \operatorname{Pr} \times 100 \% \\
\text { Sumber: Asmarantaka (2014) }
\end{gathered}
$$

Dimana :

Fs : Farmer's Share

Pf : Harga ikan cakalang di tingkat nelayan

Pr: Harga ikan cakalang di tingkat konsumen

\section{HASIL DAN PEMBAHASAN}

\section{ANALISIS STRUKTUR PASAR}

Analisis struktur pasar dijelaskan menggunakan pendekatan deskriptif kualitatif di mana analisis pangsa pasar menggunakan persentase pembelian pedagang terbesar di PPP Bacan, pembelian pedagang grosir di Pasar Tembal dan Pasar Babang. Selain itu, analisis juga dilakukan di tingkat nelayan dan perusahaaan untuk melihat posisi nelayan dan perusahaan dalam pasar ikan cakalang.

\section{a. Pangsa Pasar dan Konsentrasi Pasar}

Analisis pangsa pasar dan konsentrasi pasar diuji menggunakan data total penjualan bulanan dan pembelian yang diperoleh dari pihak PPP Bacan. Data tersebut berupa data total penjualan harian pedagang besar di PPP Bacan, nelayan dan industri perikanan bulan September 2019. Sementara data yang digunakan dalam menganalisis strukur pasar pedagang grosir menggunakan data pembelian perminggu yang diperoleh dari wawancara oleh peneliti.

Berdasarkan hasil pengujian konsentrasi pasar pedagang besar yang melakukan penjualan ikan cakalang di PPP Bacan menemukan, empat pedagang memiliki pangsa pasar sebesar 47 persen. Empat pedagang tersebut merupakan pedagang yang bekerjasama dengan nelayan lebih dari 5 sampai 11 kapal dalam penyediaan produk ikan cakalang. Berdasarkan hasil perhitungan HHI, struktur pasar yang terbentuk ialah pasar oligopsoni dengan nilai berada diantara 1000-8000. Hasil ini sesuai dengan hasil penelitian Soukotta (2015), yang menemukan struktur pasar usaha pure siene ialah oligopsoni. Pedagang besar tidak mempunyai kekuatan menetapkan harga saat melakukan penjualan ke industri perikanan yang berada di PPP Bacan. Berdasarkan hasil observasi di lapangan, pedagang mengikuti perkembangan harga yang terbentuk di PPP Bacan dengan keuntungan Rp 1,000-2,000/Kg. Sementara saat melakukan penjualan ke pengecer, PPK, grosir dan UKM, pedagang besar memiliki kekuatan menentapkan harga. Harga yang ditetapkan lebih tinggi dari harga pasar yang terbentuk di PPP Bacan.

Selanjutnya, analisis pangsa pasar pedagang grosir yang melakukan penawaran di Kabupaten Halmahera Selatan. Pedagang grosir ialah pedagang yang melakukan penawaran di pasar - pasar tradisonal Tembal dan Babang Kabupaten Halmahera Selatan. Pedagang grosir tidak memiliki hubungan langsung dengan nelayan yang berada di pusat produksi cakalang karena mayoritas nelayan 
sudah terikat dengan pedagang besar yang berada di PPP Bacan.

Berdasarkan pengujian, terdapat empat pedagang grosir menguasai 0,75 persen pangsa pasar dari total penjualan ikan cakalang di pasar lokal. Nilai CR4 menunjukan bahwa struktur pasar pada tingkat pedagang grosir ialah oligopsoni dengan tingkat konsentrasi yang sangat tinggi.

Sementara berdasarkan analisis di tingkat nelayan menemukan pangsa pasar kurang dari 50 persen. Empat responden dengan penjualan tertinggi hanya menguasai 17,45 persen pangsa pasar. Hasil analisis ini menggambarkan bahwa tingkat konsentrasi pasar ikan cakalang di tingkat nelayan sangat rendah sehingga nelayan hanya berperan sebagai price taker.

Analisis berikutnya dilakukan pada tingkat industri perikanan yang beroperasi di Kabupaten Halmahera Selatan. Terdapat 7 industri perikanan yang beroperasi di PPP Bacan dan 1 (satu) industri berada di PPI Sayoang yang melakukan pembelian ikan cakalang di PPP Bacan.

Berdasarkan hasil analisis, terdapat satu perusahaan menguasai 44,9 persen pangsa pasar. Sementara, hasil pengujian CR 4, menemukan empat perusahaan besar menguasai sekitar 85 persen pangsa pasar. Menurut Zainal et al. (2017), jika empat gabungan perusahaan besar memiliki pangsa pasar 60 persen hingga $<100$ persen maka strukutur pasar tersebut ialah struktur pasar oligopoli ketat. Waldman dan Jensen (2007) mengemukakan semakin besar pangsa pasar, maka semakin besar juga kekuatan pasar.

Berdasarkan hasil observasi di lapangan, industri perikanan merupakan lembaga pemasaran yang memiliki peran penting dalam menyerap hasil tangkap nelayan. Kemam- puan lain yaitu, industri perikanan memiliki peran dalam pembentukan harga di tingkat nelayan dengan penetapan harga standar yang menjadi acuan transaksi pembelian dan penjualan di PPP Bacan. Di mana harga yang terbentuk di lokasi penelitian dipengaruhi oleh harga yang ditetapkan oleh perusahaan sebagai dasar harga pasar ikan cakalang ditingkat produsen.

Praktek persaingan antar perusahan juga ditemukan sangat tinggi. Ketika perusahaan dengan pangsa pasar terbesar menaikkan harga maka perusahaan lain akan mengikuti perkembangan kenaikan harga walaupun tidak sebesar harga perusahaan pemimpin. Kondisi ini menunjukan bahwa terdapat satu perusahaan sebagai pemimpin pasar yang mempunyai keunggulan dalam perubahan harga sehingga perusahan-perusahaan lain di pusat produksi harus menyesuaikan setiap strategi yang diterapkan market leader.

\section{b. Hambatan Keluar Masuk Pasar}

Individu atau perusahaan dalam suatu pasar memiliki kekuatan untuk bertahan menghadapi pesaing baru yang akan masuk pada pasar tersebut. Begitupula peluang individu atau perusahaan yang berada di luar pasar untuk masuk kedalam pasar. Namun, hambatan pasar dapat mempengaruhi keputusan sebuah perusahaan atau individu untuk masuk ke dalam pasar. Berdasarkan hasil pengujian menemukan, nilai MES sebesar 14 persen, lebih besar dari 10 persen sehingga dapat disimpulkan bahwa pasar ikan cakalang memiliki hambatan masuk yang cukup berarti. Hasil ini sama dengan hasil penelitian, Bhakti et al. 2014; yang menemukan nilai MES pasar rumput laut memiliki hambatan yang cukup besar karena nilai MES > 10 persen. Berikut hasil perhitungan analisis MES :

Tabel 1. Kategori Indeks dan Status Keberlanjutan Usahatani Perkebunan Kelapa Rakyat

\begin{tabular}{ccc}
\hline $\begin{array}{c}\text { Volume Penjualan Pedagang } \\
\text { Terbesar (Kg/bulan) }\end{array}$ & $\begin{array}{c}\text { Total Penjualan Ikan di } \\
\text { PPP Bacan (Kg/bulan) }\end{array}$ & Nilai MES (\%) \\
\hline 27,500 & 196,000 & 14 \\
\hline Sumber: PPP Bacan, 2019 & &
\end{tabular}




\section{ANALISIS PERILAKU PASAR}

Perilaku pasar pemasaran ikan cakalang di Kabupaten Halmahera Selatan di analisis secara deskriptif. Elemen dalam perilaku pasar meliputi lembaga dan praktek fungsi pemasaran, saluran pemasaran, mekanisme penentuan harga dan sistem pembayaran.

\section{Praktek Fungsi Pemasaran}

Dalam praktek pemasaran hasil tangkap di Kabupaten Halmahera Selatan dari nelayan hingga konsumen melibatkan beberapa lembaga pemasaran diantaranya, pedagang besar, pedagang pengumpul Kecamatan, pedagang grosir, dan pengecer, UKM serta industri perikanan.

\section{a. Nelayan}

Nelayan dalam penelitian ini terbagi atas nelayan Pole and Line (Huhate) dan nelayan hand line. Aktivitas penangkapan berjalan setiap bulan dengan musim puncak berada di bulan Maret. Sistem penangkapan nelayan ialah one day one trip dan dalam sebulan, aktivitas penangkapan berlangsung sebanyak 15-20 kali trip tergantung musim tangkap, cuaca dan modal operasional.

Dalam melakukan pemasaran, nelayan hanya melakukan aktifitas fisik, yakni pembongkaran dan tidak menanggung biaya pembongkaran karena sudah dihitung sebagai biaya (gaji) ABK dan biaya angkut sepenuhnya ditanggung pedagang besar dan industri perikanan.

Nelayan umumnya menjual ikan cakalang ke pedagang besar dan perusahaan di PPP Bacan dan belum ada nelayan yang menjual langsung ke pedagang grosir ataupun konsumen. Nelayan handline yang menjual langsung ke konsumen bukan komoditas ikan cakalang melainkan ikan pelagis lainnya. Rata-rata ikan cakalang di jual langsung melalui dua lembaga di atas karena diikuti oleh penjualan ikan lain yakni baby tuna, tuna dan tongkol.

Resiko fisik yang dihadapi nelayan ialah kelangkaan solar, balok es, modal operasional, resiko harga, dan cuaca. Dalam memper- oleh modal operasional, nelayan dapat melakukan pinjaman ke pedagang besar dengan jaminan hasil produksi tangkap dijual ke pedagang. Pada tahap awal melaut, pembiayaan operasional ditanggung pihak KUB yakni pemilik kapal untuk menuju lokasi fishing ground. Sementara, pada hari kedua dan seterusnya, ketersedian modal operasional akan di tanggung oleh pedagang besar sebagai bagian dari kerjasama penjualan hasil nelayan. Hubungan kuat ini disebut patron klien karena kedua lembaga ini selain bekerjasama dalam penyediaan modal dan pemasaran, juga ketersediaan operasional seperti minyak, dan balok es hingga pengurusan ijin melaut kapal.

Berdasarkan perilaku pasar di tingkat nelayan, dari 68 nelayan responden, terdapat 50 (73,5 persen) responden melakukan penjualan kepada pedagang besar (pelaksana), 16 (23,5 persen) responden ke industri perikanan 2 responden $(0,02$ persen) ke pengecer. Alasan penjualan karena penyedian operasional dan kemudahan pemasaran 48,5 persen, harga tinggi 25 persen, kontrak atau hutang 1,6 persen dan ikatan kekeluargaan atau kenalan 0,08 persen.

\section{b. Pedagang Besar (Pelaksana)}

Pedagang besar atau biasa disebut pelaksana ialah pedagang yang melakukan penawaran terbesar di PPP Bacan. Selain memiliki modal yang besar, mayoritas nelayan khususnya armada tangkap Pole and Line memiliki ikatan kuat dengan pedagang besar. Kerjasama yang terjalin berupa kerjasama pemasaran hingga operasional. Selain itu, kondisi di lapangan menemukan peran penting pedagang besar ialah menjamin hasil produksi tangkap dapat terjual habis. Pedagang besar merupakan pihak utama distribusi ikan cakalang terutama ke industri perikanan dengan menjalin kerjasama penjualan. Selain itu, distribusi ke lembaga-lembaga pemasaran lain juga melalui peran pedagang besar. Jumlah responden dalam penelitian ini sebanyak 18 orang dari total 23 pedagang yang tercatat di PPP Bacan. 
Pembelian ikan cakalang dilakukan langsung kepada nelayan di mana nelayan dan pedagang besar melakukan kerjasama atau kontrak tidak tertulis dalam praktek pemasaran hasil tangkap. Pedagang besar oleh PPP Bacan diklasifikasikan berdasarkan kerjasama dari 1 sampai $>11$ kapal dalam penyediaan produk.

Tujuan pemasaran utama pedagang besar ialah industri perikanan terutama ikan cakalang berukuran $1 \mathrm{Up}(1 \mathrm{~kg})$. Setelah itu, pedagang pengumpul Kecamatan, pedagang pengecer, pedagang grosir dan UKM. Jumlah rata-rata volume penjualan perhari sebesar $1.300 \mathrm{~kg}$.

Transaksi pembelian dan penjualan lakukan di Tempat Pelelangan Ikan (TPI) PPP Bacan dan dermaga pendaratan. Walaupun menjual di TPI akan tetapi mekanisme pelelangan tidak berjalan sehingga pembentukan harga mengikuti harga beli industri dan harga yang ditetapkan oleh pedagang jika dipasarkan di luar industri.

Rata-rata pedagang menjual habis ikan cakalang dan jarang melakukan penyimpanan. Sementara sumber permodalan berasal dari modal sendiri dan hanya sedikit yang mendapatkan modal dari lembaga perbankan. Pedagang besar yang berada di lokasi PPP Bacan juga dikenai retribusi berdasarkan jumlah kerjasama dengan nelayan dengan klasifikasi kerjasama pedagang dengan nelayan di atas 6-11 kapal dikenai biaya retribusi sebesar Rp 500.000 perbulan, 3 kapal sebesar $R p$ 30.000 perbulan dan 1-3 dikenai Rp 200.000 perbulan dan 1 kapal sebesar Rp 100.000 perbulan.

\section{c. Pedagang Pengumpul Kecamatan (PPK)}

Pedagang Pengumpul Kecamatan (PPK) merupakan lembaga pemasaran yang melakukan aktivitas pemasaran keluar dari Kabupaten Halmahera Selatan. Tujuan pemasaran PPK ialah pasar Kota Ternate, Kota Bitung dan Kota Manado. Jumlah responden dalam penelitian ini berjumlah 8 responden. Jumlah ini tidak tetap tergantung dari musim, modal serta pesanan dari luar kota.
Praktek fungsi pemasaran yang dilakukan pedagang PPK ialah fungsi pertukaran (pembelian dan penjualan), fungsi fisik (pengangkutan, penyimpanan) dan fungsi fasilitas (pembiayaan). Aktivitas pembelian dilakukan setiap hari dengan volume rata-rata sebesar $687 \mathrm{~kg}$ dan perbulan 9,062 ton. Volume pembelian tergantung pada pesanan dari pedagang besar maupun pengecer di luar kota dengan mekanisme pengiriman 2 hari sekali.

Pada fungsi pengangkutan, PPK menggunakan mobil pick up ke pelabuhan terdekat dengan mengeluarkan biaya pengangkutan sedangkan biaya pengangkutan kapal laut sepenuhnya ditanggung oleh pedagang luar kota.

Mayoritas pedagang pengumpul Kecamatan mendapatkan produk dari pedagang besar. Akan tetapi, di musim-musim paceklik atau tingginya pemesanan dari luar kota, PPK melakukan pembelian ke perusahaan untuk memenuhi volume permintaan. Resiko yang dihadapi oleh PPK ialah terjadinya penyusutan ketika ikan cakalang sampai ke pedagang luar kota. Sementara untuk akses modal, PPK menggunakan modal sendiri serta melakukan pinjaman kepada sesama pedagang. Rata-rata PPK melakukan penyimpanan sebelum dikirim keluar kota.

\section{d. Pedagang Grosir}

Pedagang grosir dalam penelitian ini berjumlah 6 pedagang grosir yang tersebar di pasar Tembal dan pasar Babang Kabupaten Halmahera Selatan. Pedagang grosir tidak terhubung dengan nelayan baik dari segi permodalan, operasional hingga penyediaan produk. Penyediaan produk ikan cakalang didapatkan langsung melalui pedagang besar (100 persen). Berdasarkan hasil wawancara, sulitnya masuk pasar dan mayoritas nelayan telah terikat dengan pedagang besar di PPP Bacan menyebabkan pedagang grosir tidak terlibat sama sekali dengan aktivitas di sentra produksi. Sehingga, ikan cakalang bukan komoditas utama penjualan melainkan ikan lain. 
Aktivitas pembelian hanya dilakukan per minggu tergantung permintaan dan kondisi pasar. Tujuan pemasaran pedagang grosir ialah konsumen dan pedagang besar maupun pengecer luar kota yakni Ternate, Bitung dan Manado. Fungsi pemasaran yang dilakukan ialah fungsi pertukaran (penjualan, pembelian), fungsi fisik (pengangkutan, penyimpanan) dan fungsi fasilitas (modal, informasi pasar). Rata-rata pedagang melakukan penyimpanan jika tidak laku terjual (83 persen) dan hanya 1 pedagang yang melakukan penjualan dengan murah (16,7 persen).

\section{e. Pedagang Pengecer}

Pedagang pengecer dalam penelitian ini ialah pedagang pengecer tetap dan pedagang pengecer keliling berjumlah 15 responden. Pedagang pengecer tetap berada di PPP Bacan, pasar tradisonal Tembal dan pasar tradisonal Babang yang mempunyai tempat berjualan khusus di pasar tradisional Sedangkan, pedagang pengecer keliling ialah pedagang pengecer yang menjual ikan cakalang dengan berkeliling dari satu desa ke desa lain.

Pedagang pengecer ikan di pasar tradisional Tembal hanya melakukan penjualan ikan cakalang dan tidak melakukan penjualan ikan lain. Berbeda dengan pedagang pengecer di PPP Bacan dan pasar tradisonal Babang yang menjual ikan selain cakalang.

Fungsi pemasaran yang dilakukan pedagang pengecer ialah (fungsi pembelian dan penjualan), fungsi fisik (pengangkutan, penyimpanan) dan fungsi fasilitas (modal dan informasi pasar). Rata-rata ikan cakalang terjual habis selama dua hari, dan cenderung menyimpan ikan cakalang ketimbang menjual murah serta tidak melakukan penjualan ke pasar lain. Volume ikan cakalang yang dijual pedagang pengecer berkisar $30-50 \mathrm{Kg}$ perhari.

Perilaku pedagang pengecer dalam memperoleh produk terhubung langsung dengan pedagang besar (86,75 persen) dan datang sendiri ke nelayan sebesar 13,3 persen. Dalam praktek penjualan, jika ikan cakalang tidak terjual habis maka akan dilakukan penyim- panan (73,3 persen) ketimbang dijual murah 26,6 persen.

\section{f. UKM Ikan Asap}

Rata-rata responden UKM berdomisli di Kecamatan Tembal dan Desa Papaloang. Jumlah responden dalam penelitian ini sebanyak 8 responden. Pada fungsi fisik, pedagang melakukan pengangkutan menggunakan kendaraan pick up yang di sewa di lokasi PPP Bacan dan tidak ada pedagang yang memiliki sarana pengangkutan. Sementara untuk penyimpanan, rata-rata menggunakan coolbox diisi es. Dan hasil olahan ikan cakalang asap (fufu) terjual habis dalam sehari karena umumnya ikan cakalang asap hanya mampu bertahan 3 hari.

Dalam mendapatkan produk, rata-rata responden terhubung langsung dengan pedagang besar (75 persen) dengan cara mendatangi atau menanyakan informasi stok ke pedagang besar. Jika kapal nelayan melakukan penangkapan, maka pedagang langsung menuju lokasi PPP Bacan. Pedagang juga sering memesan diawal jika sudah mengetahui adanya informasi produksi. Selain itu terdapat pedagang yang melakukan pemesanan langsung sebanyak 2 pedagang (25 persen).

\section{MEKANISME PENENTUAN HARGA}

Penentuan harga dapat menunjukan indikasi apakah nelayan memiliki bargaining power yang kuat serta menggambarkan posisi struktur pasar ikan cakalang di Kabupaten Halmahera Selatan.

Berdasarkan Tabel 2, nelayan memiliki posisi tawar menawar (bargaining position) yang rendah dibandingkan lembaga-lembaga pemasaran lainnya yang terlibat dalam pemasaran produk perikanan. Harga yang terbentuk di lokasi penelitian berdasarkan harga yang terbentuk di industri perikanan. Harga acuan ini merupakan landasan lembagalembaga pemasaran terutama pedagang besar untuk menetapkan harga dalam memaksimalkan keuntungan. 
Tabel 2. Mekanisme Penentuan Harga

\begin{tabular}{|c|c|c|c|c|}
\hline $\begin{array}{c}\text { Lembaga } \\
\text { Pemasaran }\end{array}$ & Informasi & Pembeli & Penentuan Harga & Presentase (\%) \\
\hline \multirow[t]{4}{*}{ Nelayan } & Nelayan, & Pedagang besar & Pedagang besar & 100 \\
\hline & Pedagang, & Perusahaan & Perusahaan & 100 \\
\hline & PPP Bacan, & Pengecer & Nelayan & 85,7 \\
\hline & & & Tawar menawar & 14,4 \\
\hline \multirow{3}{*}{$\begin{array}{l}\text { Pedagang } \\
\text { besar }\end{array}$} & Pedagang, & Perusahaan & Ditentukan & \\
\hline & PPP & & Pembeli & 100 \\
\hline & & $\begin{array}{l}\text { Pegecer, UKM, } \\
\text { Pengumpul }\end{array}$ & $\begin{array}{l}\text { Ditentukan } \\
\text { Penjual }\end{array}$ & 100 \\
\hline \multirow[t]{3}{*}{ Grosir } & $\begin{array}{l}\text { Sesama } \\
\text { Pedagang }\end{array}$ & Pedagang luar kota & $\begin{array}{l}\text { Ditentukan } \\
\text { Penjual } \\
\text { Ditentukan }\end{array}$ & 66,7 \\
\hline & & Konsumen & Pembeli & 33,3 \\
\hline & Pedagang, & Pedagang luar kota & $\begin{array}{l}\text { Tawar menawar } \\
\text { Ditentukan }\end{array}$ & 100 \\
\hline \multirow[t]{2}{*}{$\begin{array}{l}\text { Pedagang } \\
\text { Pengumpul } \\
\text { Kecamatan }\end{array}$} & PPP Bacan & & $\begin{array}{l}\text { Penjual } \\
\text { Ditentukan } \\
\text { Pembeli }\end{array}$ & 62,4 \\
\hline & & & Tawar menawar & 37,5 \\
\hline Pengecer & $\begin{array}{c}\text { Sesama } \\
\text { Pedagang }\end{array}$ & Konsumen & Tawar menawar & 100 \\
\hline UKM & $\begin{array}{c}\text { Pedagang, } \\
\text { PPI }\end{array}$ & Konsumen & $\begin{array}{c}\text { Ditentukan } \\
\text { Penjual } \\
\text { Tawar-menawar }\end{array}$ & 100 \\
\hline
\end{tabular}

Sumber : Data Primer, 2019

Penentuan harga yang terbentuk di lokasi penelitian sebagian besar ditentukan oleh industri perikanan dan pedagang besar. Pada tingkat nelayan, penentuan harga ditentukan oleh perusahaan saat nelayan menjual ke industri perikanan dan berada di tangan pedagang besar saat melakukan penjualan ke pedagang besar. Harga jual ketika menjual ke pihak pedagang besar lebih rendah dari harga yang terbentuk di lokasi produksi. Kondisi tawar-menawar jarang terjadi sehingga nelayan cenderung menerima harga ditetapkan oleh 2 lembaga tersebut. Pembentukan harga yang terjadi di tingkat nelayan membuktikan bahwa struktur pasar yang terbentuk di lokasi penelitian ialah oligopsoni sesuai dengan hasil analisis struktur pasar diawal. Sehingga, peran nelayan tangkap ikan cakalang hanya sebagai price taker.

Pada tingkat pedagang besar, saat menjual ikan cakalang ke perusahaan maka perannya hanya sebagai price taker sedangkan saat menjual ikan cakalang ke pedagang grosir, pengecer dan pedagang pengumpul antar kecamatan maka peran ialah price maker. Dimana harga yang ditetapkan lebih tinggi dengan keuntungan Rp 2.000-2.500/kg. Kondisi ini terbalik ketika melakukan pembelian ke nelayan di mana harga beli lebih rendah dengan keuntungan yang sama. Selanjutnya, pembentukan harga di pedagang grosir melalui mekanisme tawar-menawar saat melakukan penjualan ikan cakalang ke konsumen. Namun, saat memasarkan ke pedagang luar kabupaten, penentuan harga ditentukan oleh pedagang grosir dengan pertimbangan biaya pembelian, biaya pemasaran dan pola pergerakan harga di pasar tujuan.

Sistem pembentukan harga ini sama dengan sistem pembentukan harga di tingkat Pedagang Pengumpul Kecamatan. Di mana mayoritas PPK menentukan harga jual dengan pertimbangan harga pasar di pasar tujuan. Sementara pada tingkat pedagang pengecer dan UKM ikan asap, proses penetuan harga yang terbentuk ialah tawar menawar dan ditentukan oleh pedagang. 


\section{SISTEM PEMBAYARAN}

Modal, hutang dan biaya operasional merupakan beberapa masalah kecenderungan nelayan tidak mempunyai pilihan saluran pemasaran. Dalam sistem pembayaran pada Tabel 3, menunjukkan pedagang besar yang bekerjasama dengan nelayan akan melakukan pembayaran setelah semua ikan cakalang terjual habis. Pembayaran dilakukan setelah melakukan pemotongan biaya operasional (minyak solar dan balok es) secara tunai ke nelayan yang dikeluarkan pedagang hari sebelumnya. Sistem pembayaran ini menandakan bahwa pedagang dalam melakukan pembelian ikan cakalang tidak membutuhkan dana yang besar. Sementara, nelayan yang melakukan penjualan ke industri perikanan akan langsung menerima pembayaran secara tunai dipotong pembelian es balok.

Sementara, pedagang grosir, melakukan pembayaran secara tunai karena volume pembelian yang kecil dan intensitas pembelian dilakukan seminggu sekali walaupun pada tingkat pemasaran ke luar Kabupaten proses pembayaran dilakukan setelah penjualan oleh pedagang luar kota.

Kondisi ini berbeda dengan pedagang pengumpul kecamatan yang melakukan pemba- yaran rata-rata secara hutang. Sebab, pembayaran pada tingkat pemasaran selanjutnya dilakukan secara bertahap dan setelah proses penjualan ikan cakalang yang berimplikasi kepada modal PPK dan tidak melakukan pembelian ikan cakalang sampai ada proses pembayaran dari pedagang dari luar kota. Sementara, pedagang pengecer dan UKM sama-sama melakukan pembayaran secara tunai dan penjualan pedagang pengecer dilakukan secara tawar menawar.

\section{SALURAN PEMASARAN}

\section{a. Saluran Pemasaran Ikan Cakalang Besar}

Setiap entitas yang menyentuh produk selama produk tersebut berpindah dari produsen ke konsumen adalah bagian dari pemasaran (Norwood dan Luck, 2008). Pemasaran ikan cakalang melibatkan lembaga-lembaga pemasaran yang membentuk saluran pemasaran. Secara ringkas, saluran pemasaran dari peneltian ini dibedakan menjadi dua, yakni saluran pemasaran ikan cakalang besar 1 UP $(1 \mathrm{Kg})$ dan cakalang kecil $(0,5)$ Perbedaan ini sesuai dengan kondisi dilapangan, di mana strukur permintaan ikan cakalang besar dan kecil sangat berbeda dan sangat mempengaruhi pendapatan tiap-tiap lembaga pema-

Tabel 3. Metode Sistem Pembayaran

\begin{tabular}{|c|c|c|c|}
\hline Lembaga Pemasaran & Pembeli & Sistem Pembayaran & Presentase \\
\hline \multirow[t]{5}{*}{ Nelayan } & PB & Tunda setelah penjualan & \\
\hline & & dan pemotongan OP & 84,4 \\
\hline & & Dibayar di awal & 0,04 \\
\hline & & Tunai & 13,3 \\
\hline & Industri & Tunai & 100 \\
\hline \multirow{6}{*}{ Pedagang Besar } & Perusahaan & Tunai & 100 \\
\hline & PPK & Hutang & 65 \\
\hline & & Tunai & 35 \\
\hline & Pengecer & Tunai & 100 \\
\hline & UKM & Tunai & 100 \\
\hline & Grosir & Tunai & 100 \\
\hline \multirow[t]{3}{*}{ Grosir } & Konsumen & Tunai & 100 \\
\hline & Pedagang Luar & Cicil $30 \%$ & 57,1 \\
\hline & Kota & Tunda setelah penjualan & 42,8 \\
\hline Pengumpul & Pedagang luar & Hutang, cicil 3 bulan & 12,5 \\
\hline \multirow[t]{2}{*}{ Kecamatan } & Kota & Cicil dibayar dimuka & 25 \\
\hline & & Tunai setelah penjualan & 62,5 \\
\hline UKM & Konsumen & Tunai & 100 \\
\hline Pengecer & Konsumen & Tunai & 100 \\
\hline
\end{tabular}


saran. Berdasarkan Gambar 2, Saluran pemasaran pada ikan cakalang besar terdapat 7 pola saluran pemasaran. Saluran pemasaran yang terbentuk tersebut ialah saluran pemasaran tingkat satu, dua dan tiga.

Rata-rata nelayan melalui saluran pemasaran tingkat 2. Saluran pemasaran terpanjang berada pada saluran pemasaran 3 dan 4 karena melakukan penjualan ke luar kabupaten. Sedangkan, saluran pemasaran terpendek yakni saluran pemasaran tingkat 1 (nelayanindustri perikanan). Gambar saluran pemasaran ikan besar di sajikan pada Gambar 2.

\section{b. Saluran Pemasaran Ikan Cakalang kecil $(0,5)$}

Selain ikan cakalang $1 \mathrm{Up}(1 \mathrm{~kg})$, saluran pemasaran ikan cakalang 0,5 juga diteliti untuk mengetahui aliran pemasaran ikan cakalang di lokasi penelitian. Hal ini karena struktur permintaan ikan cakalang kecil di dominasi oleh permintaan rumah tangga dibanding ikan cakalang besar. Walaupun demikian, volume perdagangan ikan cakalang 0,5 sangat kecil di banding volume ikan cakalang besar.
Kondisi ini dipengaruhi oleh musim tangkap dimana mayoritas hasil tangkap nelayan di dominasi oleh ikan cakalang besar saat penelitian ini dilakukan.

Berdasarkan Gambar 3, terdapat 3 saluran pemasaran yang terbentuk pada komoditas ikan cakalang kecil. Rata-rata saluran pemasaran yang terbentuk ialah saluran pemasaran tingkat 1 dan 2 . Saluran pemasaran terpendek ialah saluran pemasaran 9 yang melibatkan nelayan dan pengecer. Berikut disajikan gambaran saluran pemasaran ikan kecil

\section{MARGIN PEMASARAN DAN FARMER'S SHARE}

Penelitian ini menganalisis margin pemasaran berdasarkan ukuran ikan cakalang di lokasi penelitian. Saluran pemasaran 1, 2, 3, 4, 5, 6 dan 7 merupakan saluran pemasaran ikan Ucakalang besar ( 1 up) serta saluran pemasaran 8, 9, dan 10 merupakan saluran pemasaran ikan cakalang kecil $(0,5)$.

Berdasarkan Tabel 4, margin pemasaran ikan cakalang besar berdasarkan nilai margin tertinggi ialah saluran pemasaran 4 sebesar

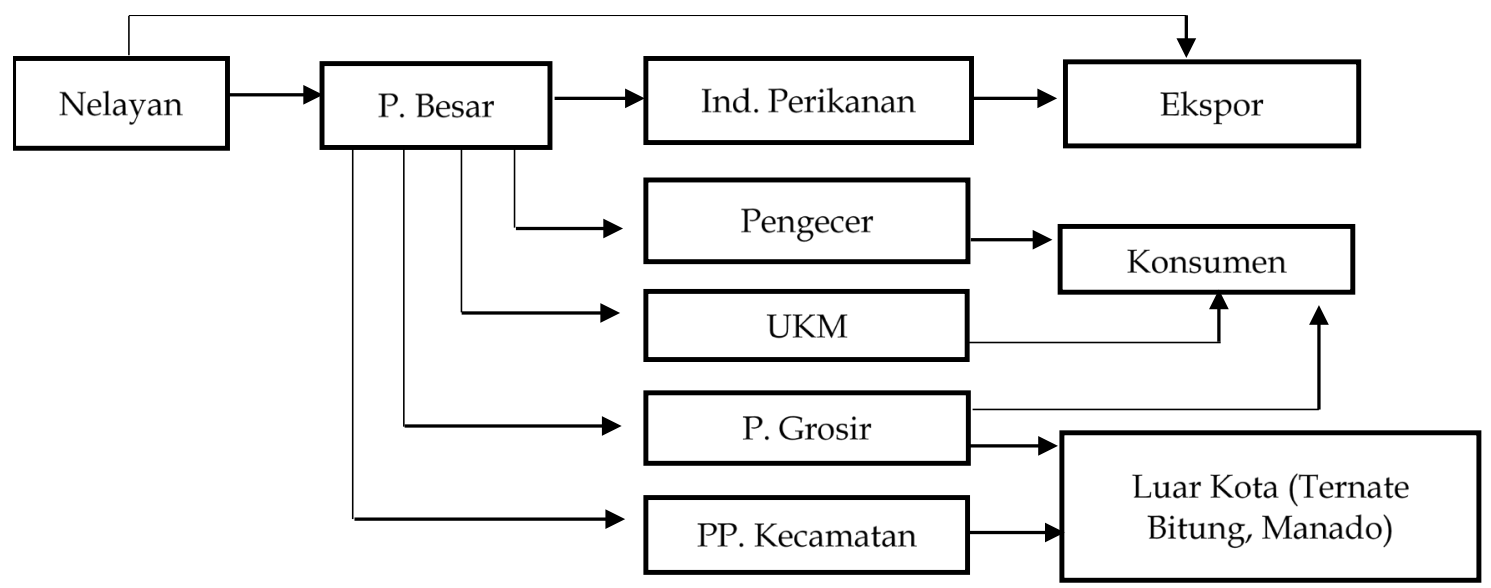

Gambar 2. Saluran Pemasaran Ikan Cakalang Besar

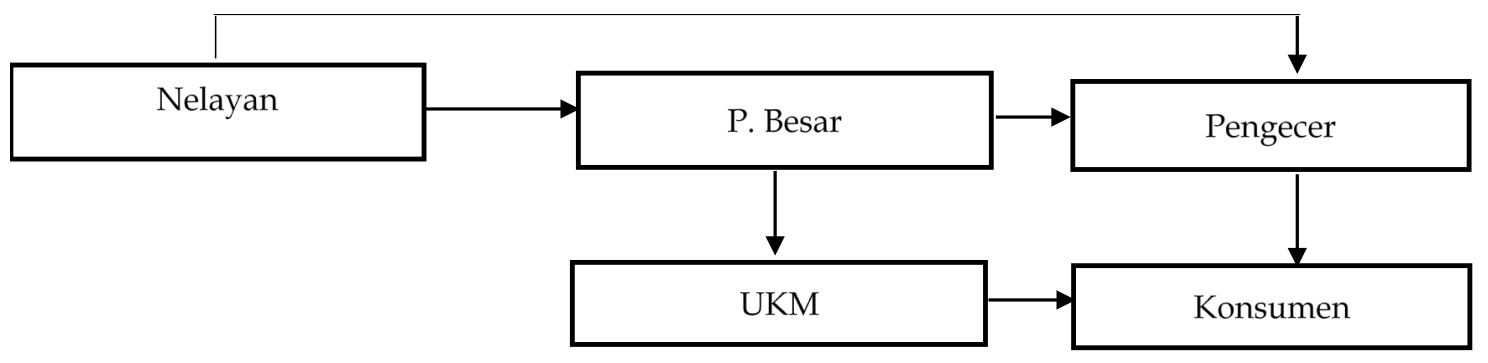

Gambar 3. Saluran Pemasaran Ikan Cakalang Kecil 
70,4 persen. Saluran pemasaran 4 merupakan saluran pemasaran yang panjang dan melibatkan nelayan, pedagang besar, pedagang grosir dan pedagang luar kota. Hasil ini sejalan dengan penelitian (Apriono et al., 2012; Hastang dan Nawawi, 2015) mendapatkan nilai marjin pemasaran yang lebih besar pada saluran pemasaran yang lebih panjang. Dimana makin panjang saluran pemasaran, makin panjang margin pemasaran yang diperoleh.

Margin pemasaran terendah ialah saluran 8 sebesar 53,9 persen. Rendahnya margin pemasaran ini karena keuntungan yang di peroleh sangat rendah walaupun hanya terdapat dua lembaga pemasaran. Hasil penelitian Kumar et al. (2017) mengungkapkan saluran pemasaran yang lebih pendek menghasilkan marjin pemasaran yang lebih kecil dibandingkan dengan saluran pemasaran yang panjang. Kondisi ini juga dipengaruhi oleh sistem pembentukan harga d imana ikan cakalang yang melalui saluran 8 merupakan harga di tetapkan oleh pedagang besar di atas harga yang terbentuk di PPP Bacan. Sementara margin saluran pemasaran ikan cakalang kecil dengan nilai margin terbesar ialah saluran 8 sebesar 73,9 persen dan terendah berada pada saluran 9 sebesar 65,1 persen.

\section{FARMER'S SHARE}

Perhitungan analisis farmer's share dalam penelitian ini juga dibedakan sesuai dengan ukuran ikan cakalang. Tabel 4 menunjukkan bahwa saluran pemasaran 1 memilki farmer share tertinggi yakni 70 persen. Tingginya nilai farmers share menunjukan bahwa nelayan yang menggunakan saluran tersebut memperoleh penerimaan yang lebih menguntungkan dibandingkan saluran pemasaran lain.

Kondisi ini karena proses penjualan ikan cakalang di saluran 1 hanya melibatkan satu lembaga pemasaran dimana lembaga pemasaran ini merupakan lembaga yang memiliki permintaan ikan cakalang tertinggi. Sesuai dengan hasil penelian Ali et al. (2015) saluran pemasaran yang hanya melibatkan satu pedagang perantara dalam memasarkan produk dari produsen sampai konsumen memiliki marjin pemasaran yang tinggi sehingga dapat dikatakan efisien. Selain itu, harga yang diterima merupakan harga yang terbentuk di pasar ketimbang memilih melakukan penjualan ke saluran 2 yang melibatkan pedagang perantara. Hal ini menunjukan bahwa saluran pemasaran secara langsung dapat memberikan keuntungan bagi nelayan.

Sementara farmer's share terendah pada ikan cakalang besar terdapat di saluran pemasaran 7 (pedagang besar dan UKM). Dimana harga ditingkat konsumen merupakan harga tertinggi dari semua saluran pemasaran yang mengindikasikan bahwa keuntungan yang diterima nelayan sangat rendah. Berikut Tabel 4 menjelaskan perhitungan margin pemasaran dan farmer,s share.

\section{KESIMPULAN DAN SARAN}

\section{KESIMPULAN}

1. Struktur pasar ikan di tingkat pedagang besar di PPP Bacan memiliki konsentrasi

Tabel 4. Margin Pemasaran dan Farmer's Share

\begin{tabular}{ccccc}
\hline Saluran & Total Biaya (Rp/kg) & Total Marjin (\%) & m/C (\%) & Farmer's Share (\%) \\
\hline 1 & - & 5,394 & - & 70 \\
2 & 477,8 & 1,569 & 1,091 & 66 \\
3 & 2.190 & 18,393 & 16,197 & 38,2 \\
4 & 2.056 & 4,467 & 4,979 & 62,8 \\
5 & 2.139 & 7,033 & 4,894 & 61,6 \\
6 & 2.441 & 17,679 & 15,237 & 38 \\
7 & 4.939 & 16,678 & 13,755 & 36 \\
\hline \multicolumn{5}{r}{ Margin Pemasaran Ikan Cakalang Kecil } \\
\hline 8 & 4.992 & 13,524 & 8,532 & 40,4 \\
9 & 1.879 & 15,345 & 12,925 & 68 \\
10 & 5.266 & 15,000 & 14,474 & 40 \\
\hline
\end{tabular}


yang cukup tinggi dilihat dari nilai CR4 mendekati 50 persen atau oligopsoni. Sementara, tingkat konsentrasi pada pedagang grosir mendekati 75 persen atau oligopoli kuat dan ditingkat perusahaan terdapat 1 perusahaan menguasai 47 persen pangsa pasar dan terdapat 4 perusahaan menguasai 82 persen pangsa pasar. Pasar ikan cakalang memiliki hambatan yang sigfikan untuk masuk dilihat dari nilai MES 14 persen

2. Perilaku pasar menunjukan bahwa nelayan tidak mempunyai kekuatan dalam penetapan harga dan hanya berperan sebagai price taker

3. Terdapat 7 saluran pemasaran ikan cakalang besar dengan margin tertinggi berada di saluran 4 sebesar 70,4 persen dan margin terendah ialah saluran 7 sebesar 53,9 persen

4. Terdapat 3 saluran pemasaran pada ikan cakalang kecil dengan saluran pemasaran terbesar berada pada saluran pemasaran 8 sebesar 73,9 persen dan terendah ialah saluran 9 sebesar 65,1 persen.

\section{SARAN}

1. Kurangnya akses nelayan terhadap permodalan, sehingga perlu adanya peran pemerintah dalam meningkatkan akses permodalan

2. Perlu adanya perbaikan sistem pelelangan di PPP Bacan agar nelayan dapat menerima harga sesuai harga pasar yang berlaku.

3. Perbaikan Infrastruktur untuk mendorong disribusi pemasaran yang efisien terutama jalan dan angkutan baik darat maupun laut.

\section{DAFTAR PUSTAKA}

Ali E, Talumingan C, Pangemanan PA \& Kumaat RM. (2015. Efisiensi Pemasaran Bawang Merah di Desa Tonsewer Kecamatan Tompaso Barat Kabupaten Minahasa. Jurnal Ilmiah Sosial Ekonomi Pertanian. 11(2A): 21-32.
Anidita R, \& Baladina N. 2017. Pemasaran Produk Pertanian. ANDI (Anggota IKAPI). Jogyakarta.

Apriono D, Dolorosa.E, \& Imelda. (2012). Analisis Efisiensi Saluran Pemasaran Ikan Lele di Desa Rasau Jaya 1 Kecamatan Rasau Jaya Kabupaten Kubu Raya. Journal Socio Economic of Agriculture, 1(3):29-36

Asmarantaka, RW. (2014). Pemasaran Agribisnis (Agrimarketing). Bogor. IPB Pres

Azhara D \& Winandi R, (2019). Analisis Efisiensi Pemasaran Ikan Bandeng di Kecamatan Tirtajaya Kabupaten Karawang. Agribusiness Forum. Vol.9 No.1 Maret 2019. ISSN 2252-5491

Bhakti, FK, Sutinah M, \& Mardiana EF. (2014). Kondisi pemasaran rumput laut Gracilaria Sp Melalui Pendekatan SCP di Kabupaten Luwu. J.Sains Teknologi, 13(3): 291-300.

Bosena DT, Bekabil F, Berhanu G,\& Dirk H. (2011). Structure, Conduct, Performance of Cotton Market: The Case of Metema District, Ethiopia. Journal of Agriculture, Biotechnology \& Ecology 4(1), ISSN: 20063938.

[BPS] Badan Pusat Statistik. 2019. Bacan Dalam Angka 2019. Badan Pusat Statistik. Kabupaten Halmahera Selatan.

[DKP] Dinas Kelautan Perikanan. 2017. Laporan Tahunan Tahun 2017. Dinas Perikanan Daerah Tingkat II Kabupaten Halmahera Selatan, Halmahera Selatan.

Fungke O, Raphel B, \& Kabir S. (2012), Market Structure, Conduct and Performance of Gari Processing Industry in South Western Nigeria. European Journal of Business and Management. ISSN 2222-1905 (Paper) Vol 4, No.2

Hastang \& Nawawi A. (2015). Saluran, Margin dan Keuntungan Lembaga Pemasaran Sapi Potong Dari Kabupaten Bone Kota Makasaar. JITP. Vol.4 No.1 Januari 2015 
Hidayati S. (2014). Struktur Pasar dan Kedudukan Indonesia Pada Perdagangan Tuna Olahan di Pasar Dunia, Jepang Dan Usa. AGRITECH : Vol. XVI No. 1 : 60 - 66 ISSN : 1411-1063.

Hikmayani Y, Tenny AP \&Achmad Z. (2007). Analisis Pemasaran Rumput Laut di Wilayah Potensial di Indonesia. Jurnal Bijak dan Riset Sosek KP.Vol.2 No.2, 2007

Irawan B. 2007. Fluktuasi Harga, Transmisi Harga, dan Marjin Pemasaran Sayuran dan Buah. Analisis Kebijakan Pertanian. 5 (4): 358-373.

[Kepmen] Keputusan Menteri Kelautan dan Perikanan Republik Indonesia Nomor 107/Kepmen-KP/2015. Rencana Pengelolaam Perikanan Tuna, Cakalang dan Tongkol

Jaya WK. 2008 .Ekonomi Industri, Edisi Kedua, BPFE, Yogyakarta. Fakultas Ekonomi Universitas Gajah Mada.

Kohls RL, Uhl JN 2002. Marketing of Agricultural Product. New Jersey (US): Prentice Hall.

Kumar R, Verma VK, \& Sharma RC.(2017). Marketing and Price Spread of Rice in Hanumangarh District of Rajasthan. International Journal of Agriculture Innovations and Research, 5(5): 697-702.

Norwood, FB \& Jayson LL. 2008. Agriculturan Marketing and Price Analysis. New Jersey: Pearson Education

Nurmalina R, Rifin A, Harmini, \& Amalia DN. (2013). Kajian Pemasaran Karet Rakyat di Provinsi Jambi. Prosiding Seminar Penelitian Unggulan Departemen Agribisnis Desember 2013, 2(1):135-150

Putri M.A, Fariyanti A \& Kusnadi N (2013). Struktur dan Integrasi Pasar Kopi Arabika Gayo di Kabupaten Aceh Tengah dan Bener Meriah. Buletin RISTRI, 4 (1): 47-54 Maret, 2013

Rahmadani, Dewi N \&Eliza (2016). Analisis Struktur, Perilaku dan Kinerja Pemasaran Ikan Salai Patin di Kecamatan XIII Koto Kampar, Kabupaten Kampar.
Indonesian Journal of Agricultural Economics (IJAE). Volume 6, Nomor 1, Juli 2016 ISSN 2087 - 409X

Soekarwati, 1998. Prinsip Dasar Ekonomi Pertanian. UI Press. Jakarta

Soukotta LM. (2015.) Analisis Efisiensi Pemasaran Usaha Pure Siene di Kota Ambon. Jurnal Wilayah dan Lingkungan. Volume 3 Nomor 1 April 2015, 15-26.

Tain, A. 2011. Penyebab Kemiskinan Rumah Tangga Nelayan di Wilayah Tangkap Lebih Jawa Timur. Jurnal Humanity Volume 7 No 1.

Thabrani, CT, Suharno \& Jahroh, S. (2018) Analisis Kinerja dan Studi Kelembagaan Pasar Ikan Hias Parung, Kabupaten Bogor (Kasus : Ikan Cupang). Jurnal Sosial Ekonomi Pertanian Vol. 15, No. 1, Februari 2018. p-ISSN 0853-8395; e-ISSN 2598-5922

Zainal A, Harahab N, \& Lina A. 2017. Pemasaran Hasil Perikanan.Universitas Brawijaya Press. Malang

Zunaidah AD, Setiawan B, Anindita R. 2015. Analisis Integrasi Pasar Apel (Kasus di Desa Sumbergo, Kota Batu, Jawa Timur). Habitat, 26(3):p.183-194. 
Lampiran 5. Struktur Pasar Pedagang Besar

\begin{tabular}{ccccc}
\hline Pedagang & $\begin{array}{c}\text { Rata-rata Volume Penjualan } \\
(\mathbf{k g} / \mathbf{b u l a n})\end{array}$ & Pangsa Pasar & CR $\mathbf{4}$ & HHI \\
\hline 1 & 27.500 & 0,140 & 47,19 & 1,632 \\
2 & 25.000 & 0,127 & & \\
3 & 20.000 & 0,102 & \\
4 & 20.000 & 0,102 & \\
5 & 15.000 & 0,076 & \\
6 & 16.000 & 0,081 & \\
7 & 15.000 & 0,076 & \\
8 & 10.000 & 0,051 & \\
9 & 10.000 & 0,051 & \\
10 & 10.000 & 0,051 & \\
\hline
\end{tabular}

Sumber : PPP Bacan (2019), diolah

Lampiran 6. Konsentrasi Pasar dan Pangsa Pasar Pedagang Grosir di Pasar Tembal dan Babang

\begin{tabular}{ccccc}
\hline Pedagang & $\begin{array}{c}\text { Rata-rata Volume Penjualan } \\
(\mathbf{k g} / \mathbf{m i n g g u})\end{array}$ & Pangsa Pasar & CR 4 & HHI \\
\hline 1 & 350 & 0,215 & 75 & 1,973 \\
2 & 350 & 0,215 & & \\
3 & 275 & 0,169 & & \\
4 & 250 & 0,153 & \\
5 & 250 & 0,153 & \\
6 & 150 & 0,169 & \\
\hline
\end{tabular}

Sumber : Data primer (2019), diolah

Lampiran 7. Pangsa Pasar 10 Nelayan Tangkap

\begin{tabular}{cccc}
\hline Nelayan & $\begin{array}{c}\text { Rata-rata Volume Penjualan } \\
(\mathbf{k g} / \mathbf{m u s i m})\end{array}$ & Pangsa Pasar & CR4 \\
\hline 1 & 13.000 & 0,051 & 0,174 \\
2 & 12.000 & 0,047 & \\
3 & 10.025 & 0,039 & \\
4 & 9.300 & 0,036 \\
5 & 8.000 & 0,031 \\
6 & 8.000 & 0,031 \\
7 & 7.500 & 0,029 & \\
8 & 6.750 & 0,026 & \\
9 & 6.750 & 0,026 & \\
10 & 6.500 & 0,025 & \\
\hline
\end{tabular}

Sumber: PPP Bacan (2019) diolah.

Lampiran 8. Struktur Pasar Industri Perikanan

\begin{tabular}{cccc}
\hline Perusahaan & $\begin{array}{c}\text { Rata-rata Volume Pembelian } \\
\text { (kg/bulan) }\end{array}$ & Pangsa Pasar & CR4 \\
\hline 1 & 152.976 & 0,449 & 0,853 \\
2 & 67.565 & 0,198 & \\
3 & 42.401 & 0,124 & \\
4 & 27.648 & 0,081 & \\
5 & 20.908 & 0,061 & \\
7 & 17.339 & 0,050 & \\
\hline
\end{tabular}

Sumber : PPP Bacan (2019), diolah 